http://doi.org/10.35784/iapgos.2656

\title{
SIMULATION AND EXPERIMENTAL RESEARCH OF CLAW POLE MACHINE WITH A HYBRID EXCITATION AND LAMINATED ROTOR CORE
}

\author{
Marcin Wardach, Pawel Prajzendanc, Kamil Cierzniewski, Michal Cichowicz, \\ Szymon Pacholski, Mikołaj Wiszniewski, Krzysztof Baradziej, Szymon Osipowicz \\ West Pomeranian University of Technology in Szczecin, Faculty of Electrical Engineering, Department of Electrical Machines and Drives, Szczecin, Poland
}

\begin{abstract}
This paper presents the design and research results of a claw pole machine with hybrid excitation. This machine is excited by permanent magnets and an electromagnetic coil. Both excitation sources are located in the rotor of the machine. Additionally, the rotor is made of a laminated core. This approach facilitates the process of its construction and enables the implementation of even very complicated structure of the rotor, which would be difficult in case of making the rotor from a one piece of material. This paper presents the construction as well as the results of simulation and experimental tests of the machine prototype. The tests showed that the proposed machine has the ability to adjust the voltage in a wide range. Such as a feature could be used, for example, to increase the speed of motor operation in case of an electric vehicle application, but also to regulate the voltage in wind turbines which generators operate at varying rotor speeds resulting from changing wind speed.
\end{abstract}

Keywords: wind energy, generators, permanent magnet machines, finite element analysis

\section{BADANIA SYMULACYJNE I EKSPERYMENTALNE MASZYNY KLOWEJ ZE WZBUDZENIEM HYBRYDOWYM I PAKIETOWANYM RDZENIEM WIRNIKA}

\begin{abstract}
Streszczenie. W pracy przedstawiono konstrukcję oraz wyniki badań maszyny kłowej ze wzbudzeniem hybrydowym. Maszyna ta jest wzbudzana od magnesów trwałych oraz cewki elektromagnetycznej. Obydwa źródła wzbudzenia znajduja się w wirniku. Ponadto wirnik ten zbudowany jest $z$ pakietowanego rdzenia. Takie podejście ułatwia proces jego budowy i umożliwia implementację nawet bardzo skomplikowanej struktury wirnika, co bytoby utrudnione w przypadku jego wykonania z jednej bryly materiału. W niniejszym artykule przedstawiono budowe oraz wyniki badań symulacyjnych i eksperymentalnych wykonanego prototypu maszyny kłowej ze wzbudzeniem hybrydowym. Badania pokazahy, że zaproponowana konstrukcja posiada możliwość regulacji napięcia w szerokim zakresie. Taka cechę można wykorzystać zarówno do zwiększenia zakresu prędkości obrotowej przy pracy silnikowej w przypadku zastosowania $w$ pojeździe elektrycznym, jak $i$ do regulacji napięcia $w$ turbinach wiatrowych, których generatory pracuja przy zmiennych prędkościach obrotowych wirnika, wynikających ze zmieniającej się prędkości wiatru.
\end{abstract}

Słowa kluczowe: energia wiatrowa, generatory, maszyny z magnesami trwałymi, metoda elementów skończonych

\section{Introduction}

One of the best known machines with a claw design is a threephase generator, i.e. an alternator. The alternator is mainly responsible for providing the right amount of electric energy, which is used to power the electric devices in cars. The alternator is mostly driven from the engine crankshaft by means of a belt transmission, therefore it must be properly adapted to work in a wide range of shaft revolutions. Such as an adaptation effectively ensures adequate charging of the battery, but also enables the use of all energy receivers located in the vehicle. And in today's vehicles, such as devices have a high demand for electricity and, at the same time, are not always resistant to any fluctuations in the supply voltage.

It is also necessary that alternator has high efficiency, thanks to which all of the components in the car will be able to work properly. In order for the alternator to work properly with the automotive electrical system, the generated voltage must be properly rectified. The alternator itself should be designed to be durable and also maintenance-free. Any slightest defect could result in a power failure and unwanted immobilization of the vehicle.

The paper presents research on a claw pole machine, which can also be used as an alternator in cars, but besides, it could be a generator of a low-power wind turbine or an electric vehicle drive motor.

\section{Machines with hybrid excitations}

Hybrid excited motors and generators are machines that combine the features of two machines in their design. It means a machine with permanent magnets and machines with excitation windings. Due to this design, these machines have much better properties. Synchronous machines with hybrid excitation are characterized by having two sources of excitation $[5,6,9,10]$. The first is the excitation that comes from permanent magnets.
The second one comes from the use of additional windings powered by direct current.

Considering the machine in the context of operation in the motor regime, using the pulse width modulation (PWM) method, it is possible to lower the average value of the motor supply voltage, and thus reduce the rotational speed of its rotor. However, this method cannot increase the motor speed above the idle speed. The maximum rotational speed is determined by the voltage induced in the armature, which is proportional to the product of the flux and the angular velocity. Being able to weaken the field it will be possible to influence on the flux, which also decreases. Furthermore, the value of induced voltage in armature decreases also to the state before increase. When the flux changes, the torque changes also. The changed torque is equal to the product of the associated flux and the armature current. During flux changes, the product of torque and angular velocity is the same all the time and does not change. Because of that we have constant power on the shaft.

Excitation with strong permanent magnets causes difficulties in obtaining a rotational speed higher than the rated speed. Obtaining a speed above, the rated speed is possible with increasing the supply voltage or weakening the field. The second method is used in motors with a sinusoidal field distribution with magnets embedded in the rotor. The field weakening is obtained at high armature currents and causes a large reduction in the efficiency of the machine. This loses one of the main advantages of these machines. Weakening the field in this way will create additional potential problems. In the event of a disturbance, in the operation of the inverter, large currents flow, which may cause a serious failure of the drive system.

Of course there are also other methods of adjusting the rotational speed. Alternatively, the supply voltage can be increased to increase the speed or apply the $d$-axis current strategy [2]. However, such methods will make the power electronic system powering the motor more complicated. 


\section{Topologies of claw pole machines}

Many constructions with claw pole topology are known With some of them, there may be some limitations; the lack of a controlled excitation flux or requiring special areas where the leakage flux is limited. Structures of this type can be used, for example, in electric car drives and in wind farms as generators.

In machines with a claw construction, the excitation winding is located between the centers of the rotor. In this machine we have a standard excitation coming from the rotor windings Additionally, the permanent magnets are also used. With this permanent magnet structure, there are two main ways to arrange the permanent magnets. The first method (Fig. 1) gives the possibility of placing permanent magnets on the claw poles [11], another possibility allows to place the magnets between the rotor poles (Fig. 2) [7]. Such as a solution necessitates the use of additional solutions, magnetic barriers in the area of the rotor, which will reduce the flux leakage, because a part of the magnetic flux in this structure could close inside the rotor itself, without passing into the air gap.

Another solution (Fig. 3) of the claw pole machine may be the concept where the claws are placed on the stator, while the permanent magnets are mounted on the rotor surface [3].

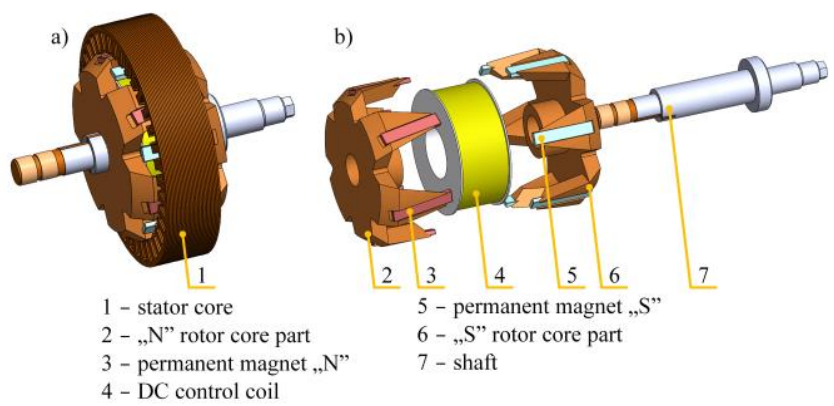

Fig. 1. Hybrid excited claw pole machine with permanent magnets mounted on claws [11]: a) stator and rotor, b) rotor in exploded view
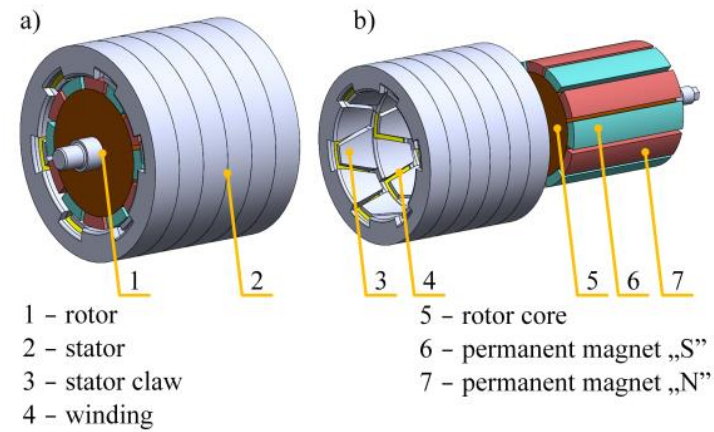

Fig. 3. Machine with claws on stator [3]: a) stator and rotor, b) exploded view

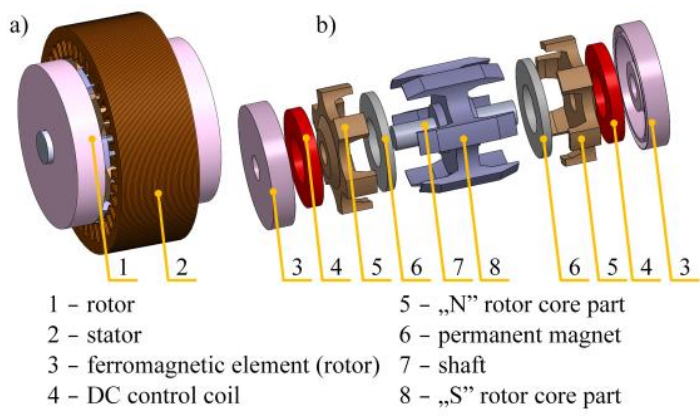

Fig. 5. Hybrid excited claw pole machine with stationary DC control coils [8]: a) stator and rotor, b) rotor in exploded view
However, such as a structure does not have flux excitation regulation. In addition, it requires the use of the technique of sintering magnetic composites.

Another possible solution (Fig. 4) is to place the magnets on the outer rotor and the claw poles on the inner stator [4].

There are also constructions of a claw pole machine with hybrid excitation in which the permanent magnets are located in a toroidal form and are located on separate cores (Fig. 5) [8]. One of the more serious disadvantages of this construction of machines is the complex structure which makes it difficult to easily and quickly build such a machine. The advantage of this design is the absence of slip rings and brushes as the excitation coils are stationary. Unfortunately, such a solution forces the excitation flux to pass from the coils through two air gaps, which can limit the control possibilities.

The paper [1] presents the concept of a claw pole machine with an external stator and a stationary excitation control system (Fig. 6). However, the rotor is made of claw poles and permanent magnets attached in their vicinity. In this case, the lack of brushes and rings is advantageous, but it is also a structurally very complicated solution. Moreover, the magnetic flux from the excitation control system must also cross two air gaps, which increases the flux leakage from the stationary excitation coil.

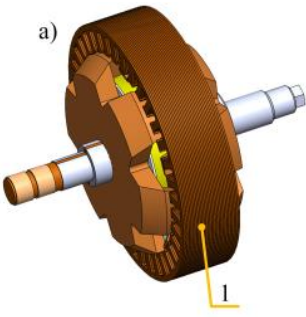

1 - stator core

2 - „N" rotor core part

3 - DC control coil

4 - permanent magnet ,S” b)

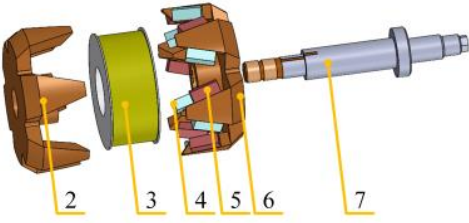

5 - permanent magnet , $\mathrm{S}$ ” $6-$, ,N" rotor core part 7 - shaft
Fig. 2. Hybrid excited claw pole machine with permanent magnets mounted between claws [7]: a) stator and rotor, b) rotor in exploded view a)

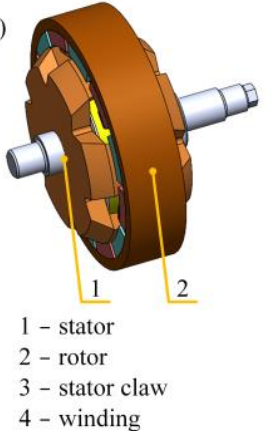

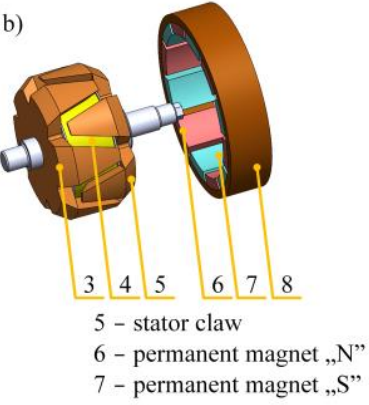

8 - outer rotor core
Fig. 4. Claw pole machine with outer rotor [4]: a) stator and rotor, b) exploded view

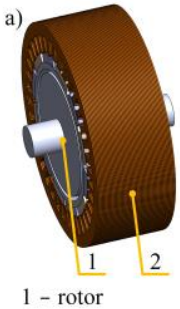

b)

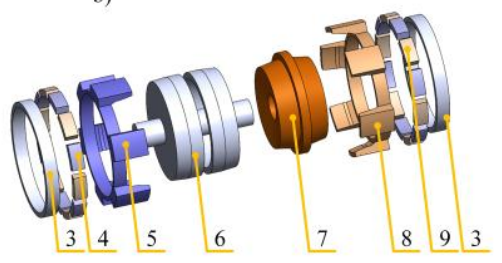

2 - stator

6 - rotor core with shaf

7 - DC control coil

- ferromagnetic ring (rotor) $8-$-,S” rotor core part

4 - permanent magnet „N" 9 - permanent magnet „S"

5 - „N" rotor core part

Fig. 6. Hybrid excited claw pole machine with stationary DC control coil [1]: a) stator and rotor, b) rotor in exploded view 


\section{Research model of a claw pole machine with hybrid excitation}

Initial simulation studies and visualization of the concept of a hybrid excited claw pole machine with a laminated rotor were presented in the previous publication. This paper [12] presents the relationship between the volume of used magnetomotive force sources in the form of permanent magnets and the parameters of the machine itself. In line with the conclusions, it was decided to build an experimental model with $15 \mathrm{~mm}$ wide magnets, but an additional change was made to [12], i.e. all coils of each phase were connected parallely to reduce the induced voltage. This model is the subject of the research presented in this paper. Figure 7 shows a visualization of the constructed machine. The basic parameters of the machine are summarized in Table 1.

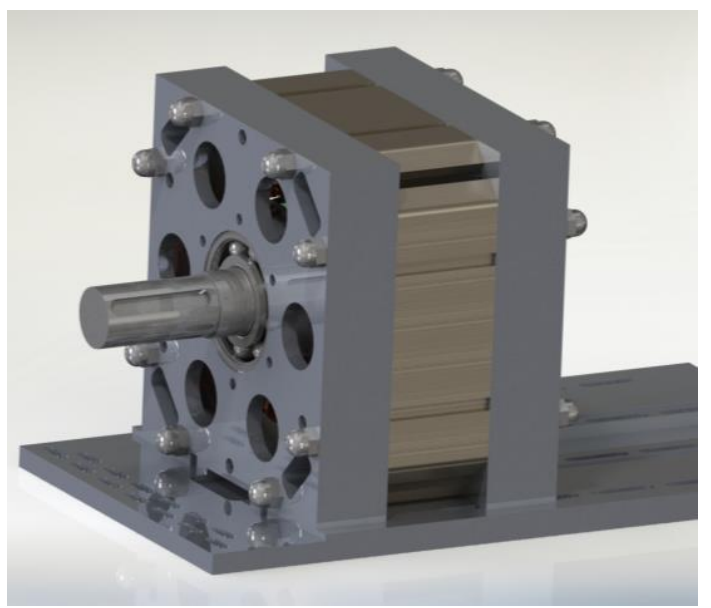

Fig. 7. Visualization of the prototype of a claw pole machine

Table 1. Basic parameters of the machine

\begin{tabular}{|l|c|c|}
\hline \multicolumn{1}{|c|}{ name } & symbol & value \\
\hline number of poles & $p$ & 12 \\
\hline external dimensions of the stator plates & $a \times a$ & $326 \times 326 \mathrm{~mm}$ \\
\hline inner diameter of a stator & $i_{d s}$ & $164 \mathrm{~mm}$ \\
\hline number of stator slots & $s$ & 36 \\
\hline outer diameter of a rotor & $o_{d r}$ & $162 \mathrm{~mm}$ \\
\hline PM width & $w_{P M}$ & $15 \mathrm{~mm}$ \\
\hline PM thickness & $t_{P M}$ & $3 \mathrm{~mm}$ \\
\hline machine length & $l$ & $100 \mathrm{~mm}$ \\
\hline air gap & $g$ & $1 \mathrm{~mm}$ \\
\hline number of turns of DC control coil & $z_{D C}$ & 1800 \\
\hline
\end{tabular}

The machine has 6 pairs of poles. The rotor claws were obtained by appropriate arrangement of the three types of rotor plates (Fig. 8). The sheets of the first type ("1" on Fig. 8) with a thickness of $10 \mathrm{~mm}$ are made of carbon steel. They are a path only for the flux of one type of poles, which means that the initial sheet conducts the magnetic flux from the " $N$ " pole, and the end from the " $S$ " pole. Therefore, the sheets " 1 " are rotated 180 electrical degrees with respect to each other.

The sheets of the second type ("2" on Fig. 8) are made of M400-50A electrical steel with a thickness of $0.5 \mathrm{~mm}$. These are packed of 20 sheets with a total thickness of $10 \mathrm{~mm}$ and are a path for a single type of flux (similar to the first type of sheets), but there are opposite pole ends between the poles. The two packages are also rotated 180 electrical degrees to each other.

Sheets of the third type (" 3 " on Fig. 8) are also made of M400-50A steel, they are the continuations of the poles of both types (" $N$ " and " $S$ "). The sheets of the first type protrude beyond the stator area, while the second and third types have magnetic bridges $1 \mathrm{~mm}$ thick and are coplanar with the stator plates. Bridges perform a mechanical function and are so narrow that they are completely saturated.

Inside the rotor's core (in the area of the third type of metal sheets) there is a coil that regulates the excitation flux. The whole is put on the steel shaft, which is also a path for the magnetic flux from the magnets and the rotor coil.
The three-phase stator has 36 slots in which 36 coils are placed in a two-layer arrangement. All coils of a given phase are connected parallely, so the phase windings have 12 parallel branches.

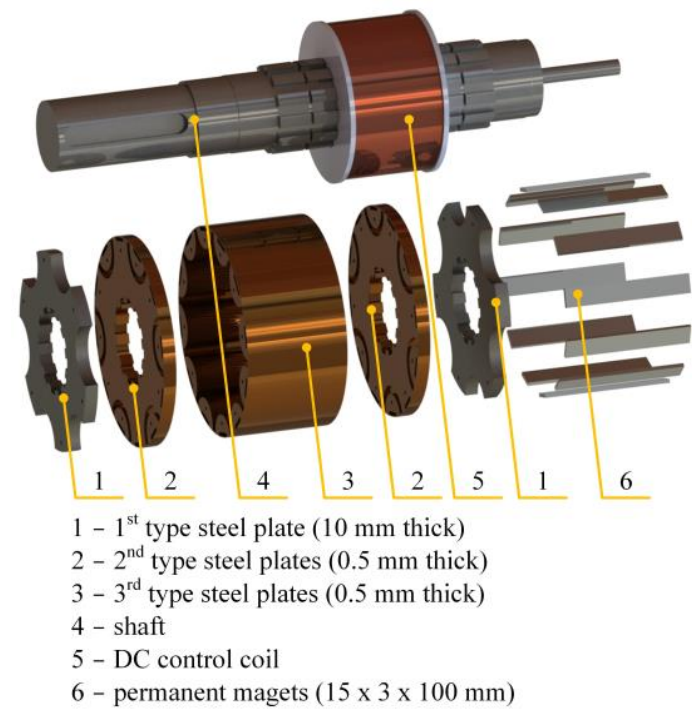

Fig. 8. The rotor of the claw pole machine prototype in an exploded view

\section{Results of simulation tests}

Figure 9 shows the simulation model of the tested claw pole machine.

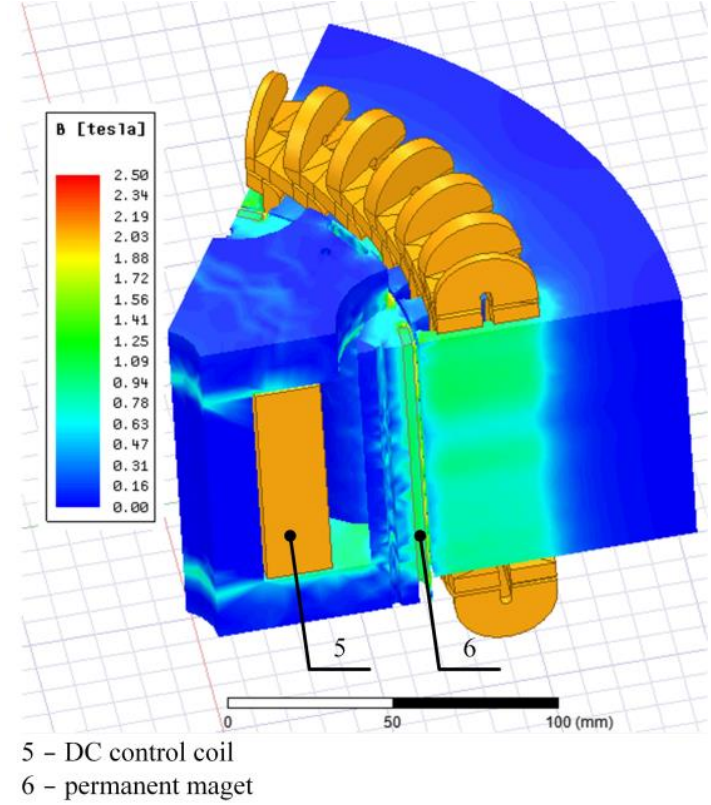

Fig. 9. FEA model of the claw pole machine

During the simulation tests, the induced voltage waveforms, the cogging torque and the electromagnetic torque of the machine were determined in various power conditions of the rotor excitation coil. Figure 10 shows the waveforms of the voltage induced in the selected machine phase for currents in the rotor coil from $-3 \mathrm{~A}$ to $3 \mathrm{~A}$.

The next figure (Fig. 11) shows the waveforms of the backemf induced between two phases, assuming the association of phases into a star.

The result of the cogging torque as a function of the excitation current is shown in figure 12 .

The electromagnetic static torque as a function of the stator current and the current in the DC rotor control coil was also tested. Examples of waveforms (for stator current $I_{s}=20 \mathrm{~A}$ ) are shown in the next figure (Fig. 13). 


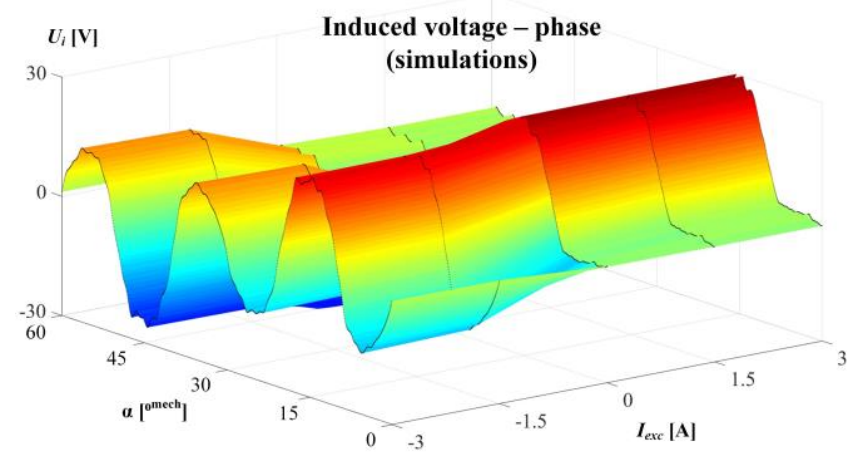

Fig. 10. Induced phase voltage - simulations

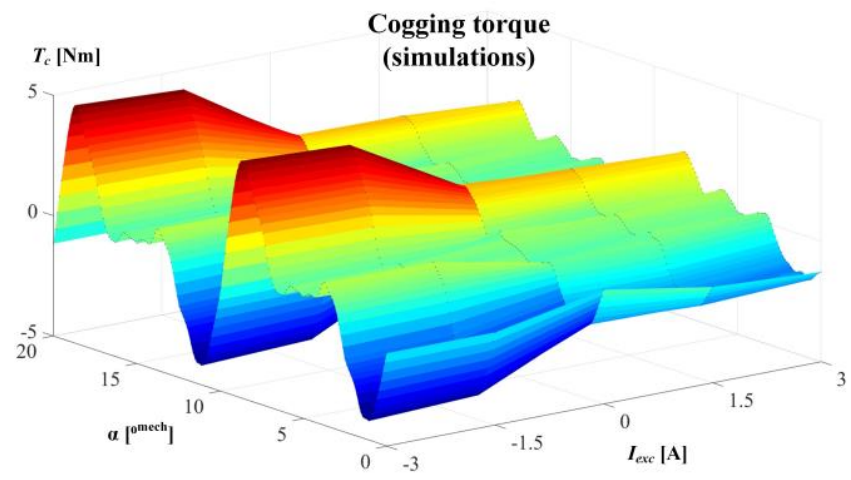

Fig. 12. Cogging torque - simulations

\section{Results of an experimental research}

Based on the simulation tests performed, an experimental model of a claw machine with hybrid excitation and a laminated rotor core was built. Figure 14 shows the experimental stand to test the prototype.

The waveforms of back-emf phase and phase-to-phase voltages are presented in the next figures 15 and 16.

Figure 17 shows the cogging torque as a function of the current in the rotor coil $I_{\text {exc }}$, while Figure 18 shows the waveforms of the electromagnetic torque measured in a static state. During this study, the machine was star connected. One of the phases is connected to the positive pole of the DC power supply and the negative pole to the other two phases connected parallely. These tests are analogous to those carried out in the simulation.

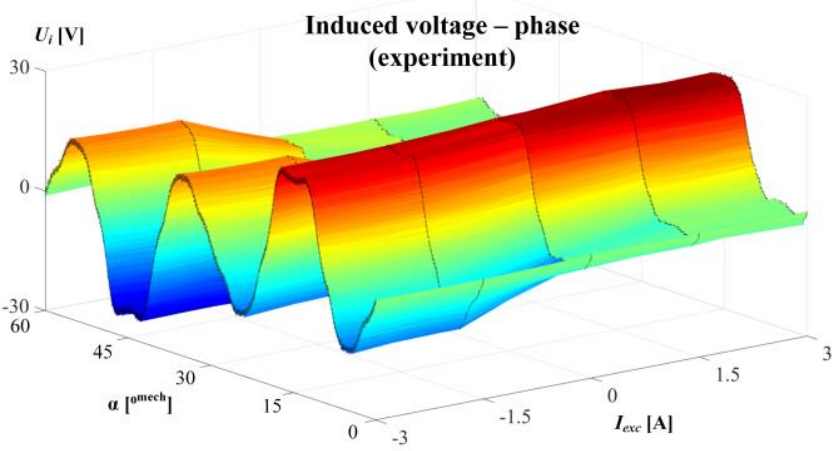

Fig. 15. Induced phase voltage - experiment

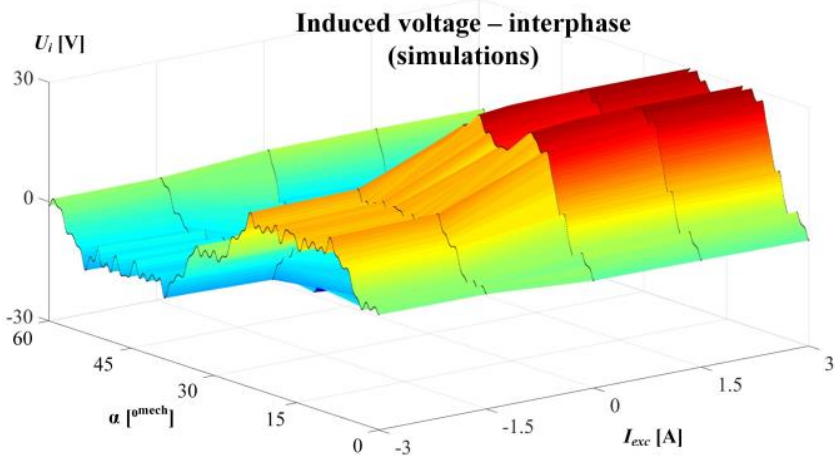

Fig. 11. Induced phase-to-phase voltage - simulations

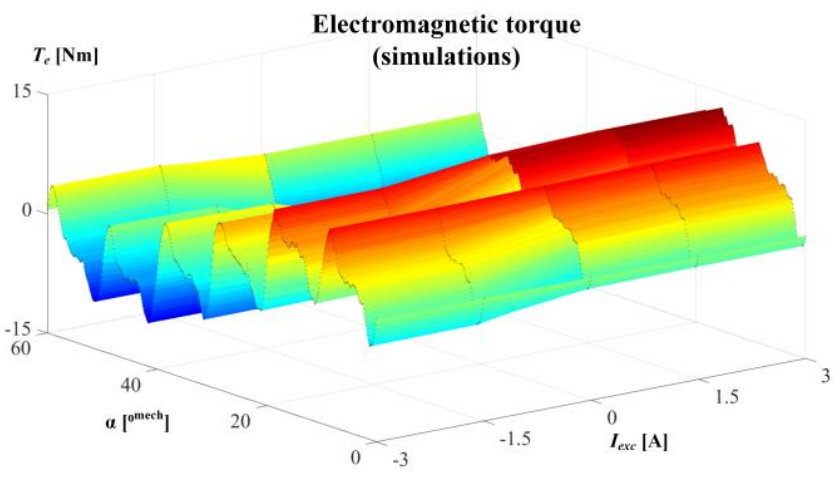

Fig. 13. Electromagnetic torque - simulations

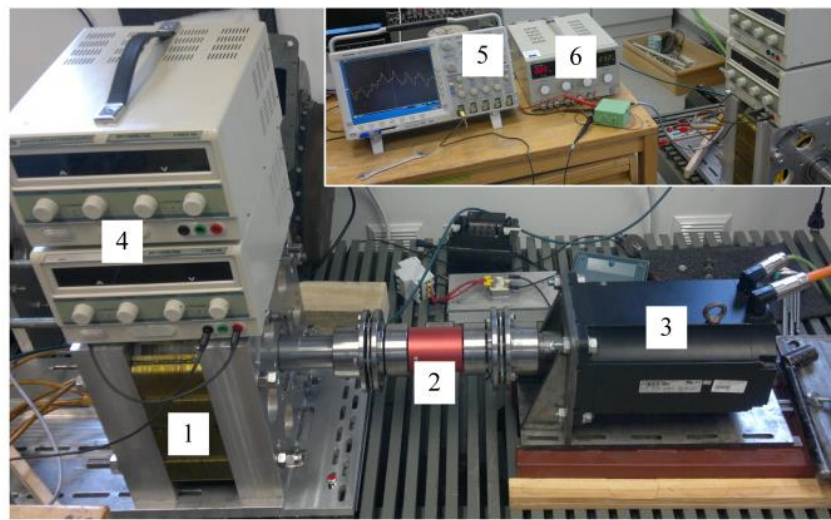

1 - claw pole machine prototype

2 - torque meter

3 - driving machine

4 - DC power suppliers for stator windings

5 - oscilloscope

6 - DC power supplier for rotor control coil

Fig. 14. Experimental stand to test the claw pole machine prototype

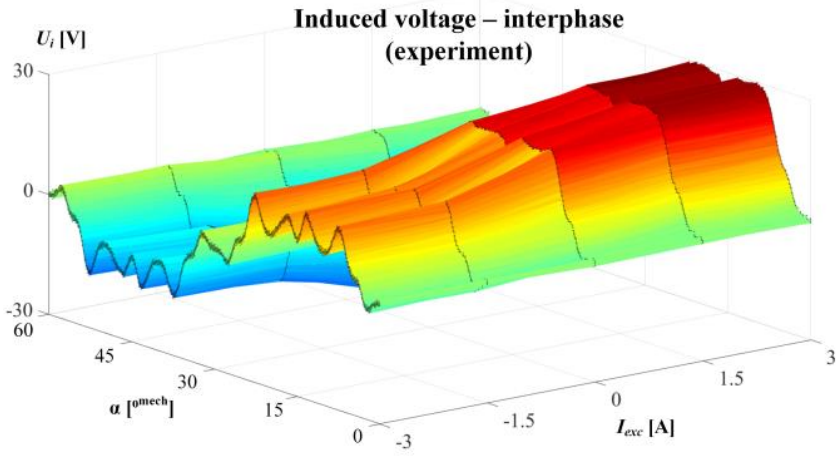

Fig. 16. Induced phase-to-phase voltage-experiment 


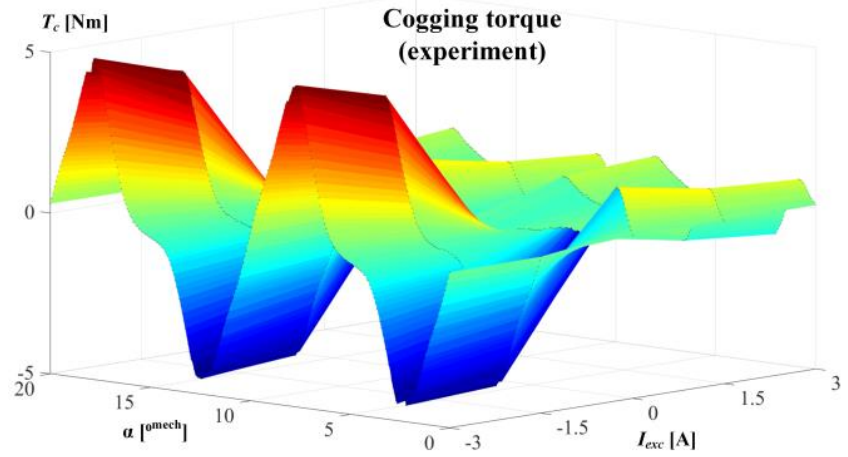

Fig. 17. Cogging torque - experiment

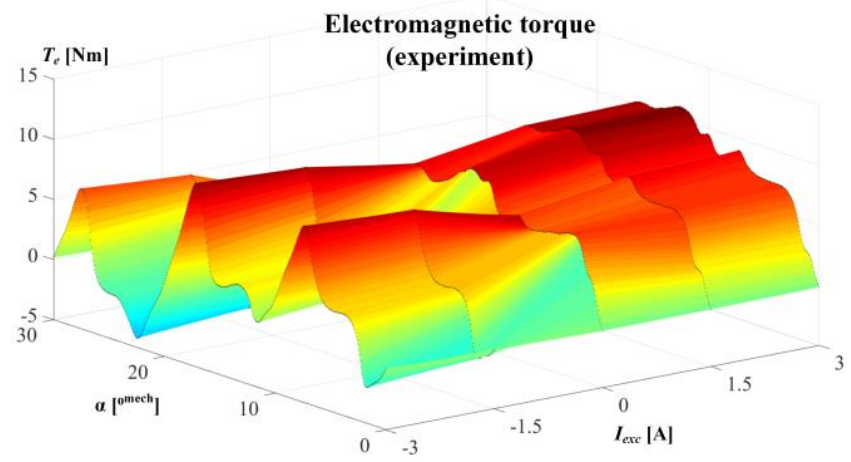

Fig. 18. Electromagnetic torque - experiment

\section{Comparison of research results}

Comparing the results of simulation and experimental studies, it is possible to come to very interesting conclusions. Figure 19 shows the change in the rms value of the induced voltage depending on the excitation current for phase (red color) and phase-to-phase (blue color) voltages obtained during simulation and experimental tests.
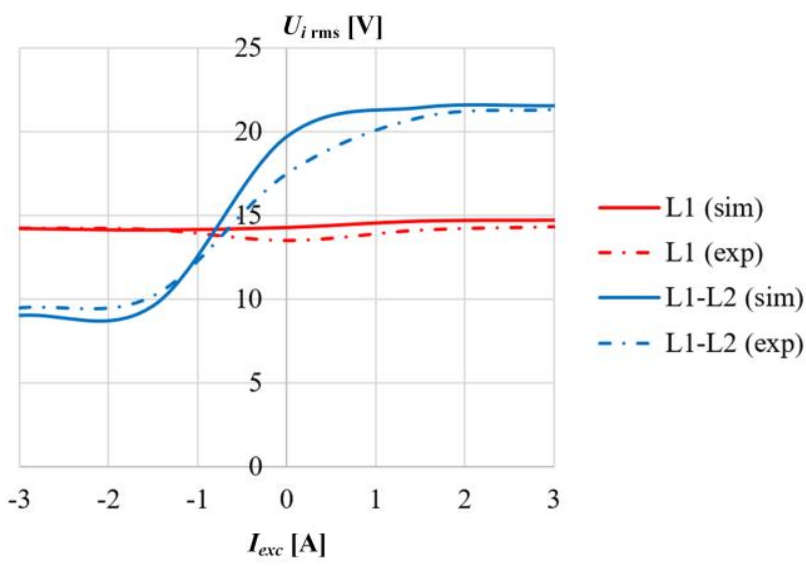

Fig. 19. Rms value of back-emf vs. excitation current $I_{\text {exc }}$

A similar comparison for the maximum voltage values is shown in the next figure 20.
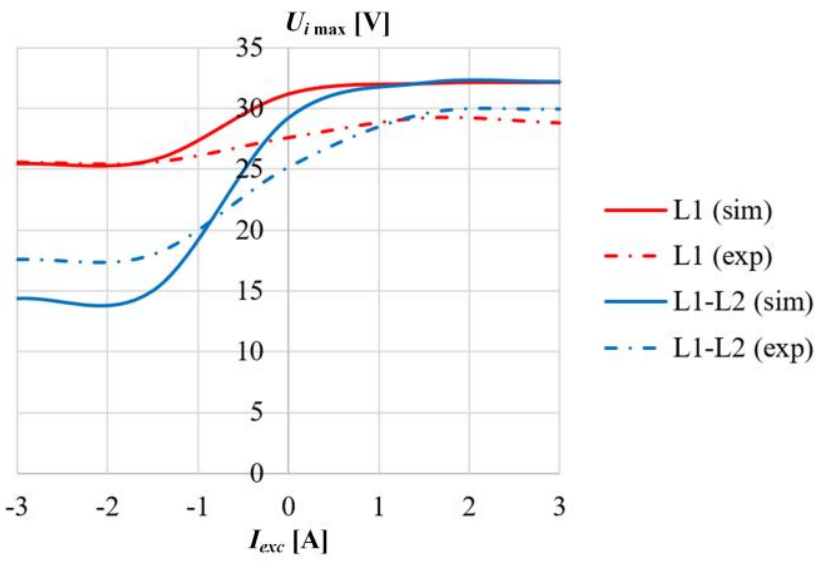

Fig. 20. Maximal value of back-emf vs. excitation current $I_{\text {exc }}$

Moreover, the results of the research in terms of the cogging torque, presented in figure 21 , were compared.
Comparing the obtained results of simulation and experimental tests, it can be concluded that the numerical model correctly reflects the real prototype. Analyzing the results, there can be seen that the parameters of the machine do not obviously change depending on the value of the current in the excitation coil $I_{e x c}$. Figure 19 shows that the root mean square value of the induced voltage for phase waveforms changes insignificantly, while the rms value of phase-to-phase voltages changes in the range from approx. $9 \mathrm{~V}$ to approx. $21 \mathrm{~V}$, i.e. FCR (field control range) is as high as 2.33 . The maximum voltage value changes slightly differently, ranging from $25 \mathrm{~V}$ to $32 \mathrm{~V}$ for phase voltages and $14 \mathrm{~V}$ to $32 \mathrm{~V}$ for phase-to-phase voltages (see Fig. 20).

In case of the cogging torque, increasing the excitation does not cause significant changes in the cogging torque (see Fig. 21), but in the field of decreasing, this torque increases from about $2 \mathrm{Nm}$ to about $5 \mathrm{Nm}$. The increase in pulsation is also clearly visible in case of the electromagnetic torque, which is also shown in figure 13 (simulations) and figure 18 (experiment).

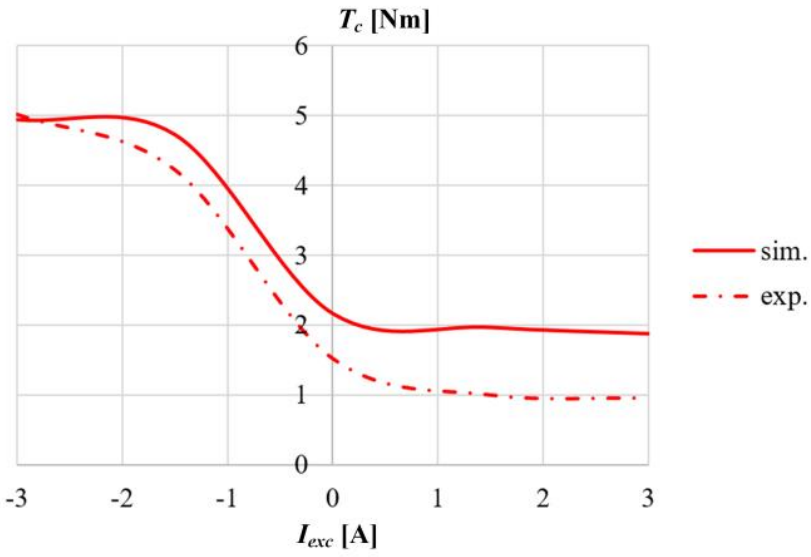

Fig. 21. Maximum value of the cogging torque

\section{Conclusions}

As a part of the research, simulation and experimental analysis of the parameters of a claw pole machine with hybrid excitation having a laminated rotor core were carried out. The paper presents the numerical and experimental model of the machine as well as the analogous test results. The influence of the current in the excitation coil on the induced phase and phase-to-phase voltage as well as on the cogging and electromagnetic torque was investigated.

The research shows that despite the fact that the rms value of the induced phase voltage changes slightly, when the machine is star-connected, a wide range of interfacial voltage regulation is visible, for which the FCR coefficient is 2.33. According to the authors, such a dependence results from the complicated 
shape of the induced voltage waveform, in which there are maxima and minima in appropriate time ranges. The resultant phase-to-phase voltage, which results from the difference between the instantaneous values of the voltages in the two phases, results in a wide adjustment range.

In case of torque tests, the conclusion is as follows: flux straightening does not cause a visible increase in the pulsation of the cogging and electromagnetic torque, while the higher the current in the field of weakening, the greater the cogging torque and pulsations of the electromagnetic torque.

\section{Acknowledgments}

This work has been supported with the grant of the National Science Centre, Poland 2018/02/X/ST8/01112.

\section{References}

[1] Burkhardt Y., Schleicher K., Klöpzig M.: A novel hybrid excited synchronous machine for (H)EV applications, IEEE Xplore, 2014

[2] Di Barba P., Mognaschi M.E., Bonislawski M., Palka R., Paplicki P., Piotuch R., Wardach M.: Hybrid excited synchronous machine with flux control possibility. International Journal of Applied Electromagnetics and Mechanics 52/2016, 1615-1622 [http://doi.org/10.3233/JAE-162190].

[3] Guo Y., Zhu J., Dorrell D., Lu H. Y., Wang Y.: Development of a Claw Pole Permanent Magnet Motor with a Molded Low-Density Soft Magnetic

\section{D.Sc. Ph.D. Eng. Marcin Wardach}

e-mail: marcin.wardach@zut.edu.pl

Marcin Wardach was born in Barlinek, Poland in 1980. He graduated and received a Ph.D. degree from the Electrical Department, Szczecin University of Technology, Szczecin, Poland, in 2006 and 2011, respectively. From 2020 until now, he has been an Associate Professor with the Faculty of Electrica Engineering, West Pomeranian University of Technology, Szczecin. His research interests include the design of electrical machines and drives.

http://orcid.org/0000-0002-1017-9054

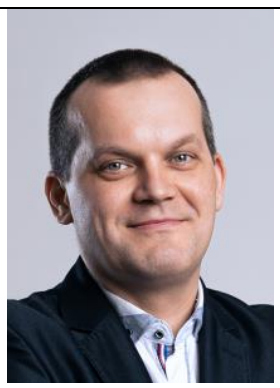

\section{MSc. Eng. Pawel Prajzendanc}

e-mail: pawel.prajzendanc@ @ut.edu.pl

Paweł Prajzendanc was born in Pyrzyce, Poland in 1990. Received a B.S. degree in electrical engineering from West Pomeranian University of Technology, Szczecin, Poland in 2015 and an M.S degree in 2017. He is currently pursuing a $\mathrm{Ph} . \mathrm{D}$. degree in electrical engineering at the Faculty of Electrical Engineering, West Pomeranian University of Technology, Szczecin, Poland. His awards and honors include a scholarship of Prime Minister of Poland. His research interests include the design of electrical machines and drives.

http://orcid.org/0000-0002-1662-4390

\section{Eng. Kamil Cierzniewski
e-mail: cierzniewski_kamil@zut.edu.pl}

Kamil Cierzniewski was born in Koszalin, Polan in 1997. Received a B.S. degree in electrical engineering for West Pomeranian University of Technology, Szczecin, Poland in 2020. He is currently pursuing M.Sc. degree in electrical engineering at the Faculty of Electrical Engineering, West Pomeranian University of Technology, Szczecin, Poland. He is a president of Student's Science Club of Association of Polish Electrical Engineers. His research interests include the design of electrical machines and drives.

http://orcid.org/0000-0003-3453-5233

\section{Eng. Michal Cichowicz
e-mail: michal_cichowicz@zut.edu.pl}

Michał Cichowicz was born in Gubin, Poland in 1998 Received a BEng degree in automatic contro and robotics from West Pomeranian University of Technology Szczecin, Poland in 2021. He is currently pursuing two MEng degrees: electrical engineering and mechanical engineering. $\mathrm{He}$ is also a president of Student's Science Club of Practical Robotics "SKORP". His research interests include: the design of electrical machines and drives; robotics; mathematics.

http://orcid.org/0000-0002-8258-0330
Composite Stator Core, Proceedings of IEEE Energy Conversion Conference \& Expo 2009, 294-301.

[4] Guo Y., Zhu J. G., Zhong J. J., Wu W.: Core Losses in Claw Pole Permanent Magnet Machines With Soft Magnetic Composite Stators. IEEE Transactions on Magnetics 39(5)/2003, 3199-3201.

[5] Hua H., Zhu Z.Q., Zhan, H.: Novel Consequent-Pole Hybrid Excited Machine with Separated Excitation Stator. IEEE Transactions on Industrial Electronics 63/2016, 4718-4728.

[6] Jahns T. M.: Flux-weakening regime operation of an interior permanent-magnet synchronous motor drive. IEEE Transactions on Industrial Application 23/1987, 681-689.

[7] Leroy V., Foveau V.: Claw rotor equipped with an insulator for an excitation coil and magnets, and rotary electrical machine equipped with a claw rotor, patent US 20130009504 A1, 2013.

[8] Melcescu L., Cistelecan M. V., Craiu O., Popescu M.: Numerical Analysis of Claw Pole Synchronous Machine with Hybrid Contactless Excitation. Electrical Review 7b/2012, 106-109.

[9] Wang Y., Deng Z.: Hybrid Excitation Topologies and Control Strategies of Stator Permanent Magnet Machines for DC Power System. IEEE Transactions on Industrial Electronics 59/2012, 4601-4616.

[10] Wardach M., Paplicki P., Palka R.: Hybrid Excited Machine with Flux Barriers and Magnetic Bridges. Energies 11/2018, 676 [http://doi.org/10.3390/en11030676].

[11] Wardach M.: Hybrid excited claw pole generator with skewed and non-skewed permanent magnets. Open Physics 15/2017, 902-906 [http://doi.org/10.1515/phys-2017-0108].

[12] Wardach M.: The Influence of Permanent Magnet Amount on No-load Parameters of Hybrid Excited Claw Pole Machine with Laminated Rotor Selected Issues of Electrical Engineering and Electronics (WZEE'2018), Szczecin, Poland, 2018.

\section{Szymon Pacholski}

e-mail: szymon_pacholski@zut.edu.pl

Szymon Pacholski was born in Goleniów, Poland in 1997. He graduated from Zespół Szkół ElektrycznoElektronicznych w Szczecine as electrotechnician. In 2018 he started studying at West Pomeranian University of Technology. His research interest include design of vehicle drives, electrical machines and mechanical issues.

http://orcid.org/0000-0002-7588-4168

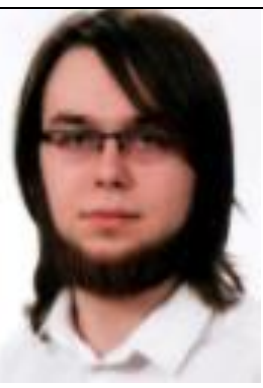

\section{Mikolaj Wiszniewski
e-mail: wm46928@zut.edu.pl}

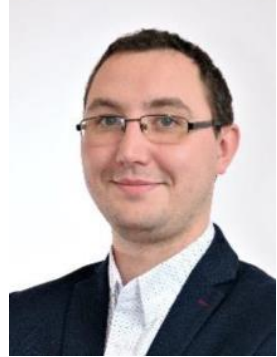

Mikołaj Wiszniewski was born in Szczecin, Poland in 1999. He is graduate of technical school on mechatronics science profile. In 2019 he became student at West Pomeranian University of Technology on automation and robotics profile. His research interests include the design of electrical machines, PLC drivers and programming manipulators.

http://orcid.org/0000-0002-8258-8922

Krzysztof Baradzie

e-mail: bk42039@zut.edu.pl

Krzysztof Baradziej was born in Szczecin, Polan in 1997. He is graduate of technical school on electronics science profile. In 2017 he became student at West Pomeranian University of Technology on electrotechnical profile. His research interests include microcontrolers and li-ion cells.

http://orcid.org/0000-0003-1293-3409
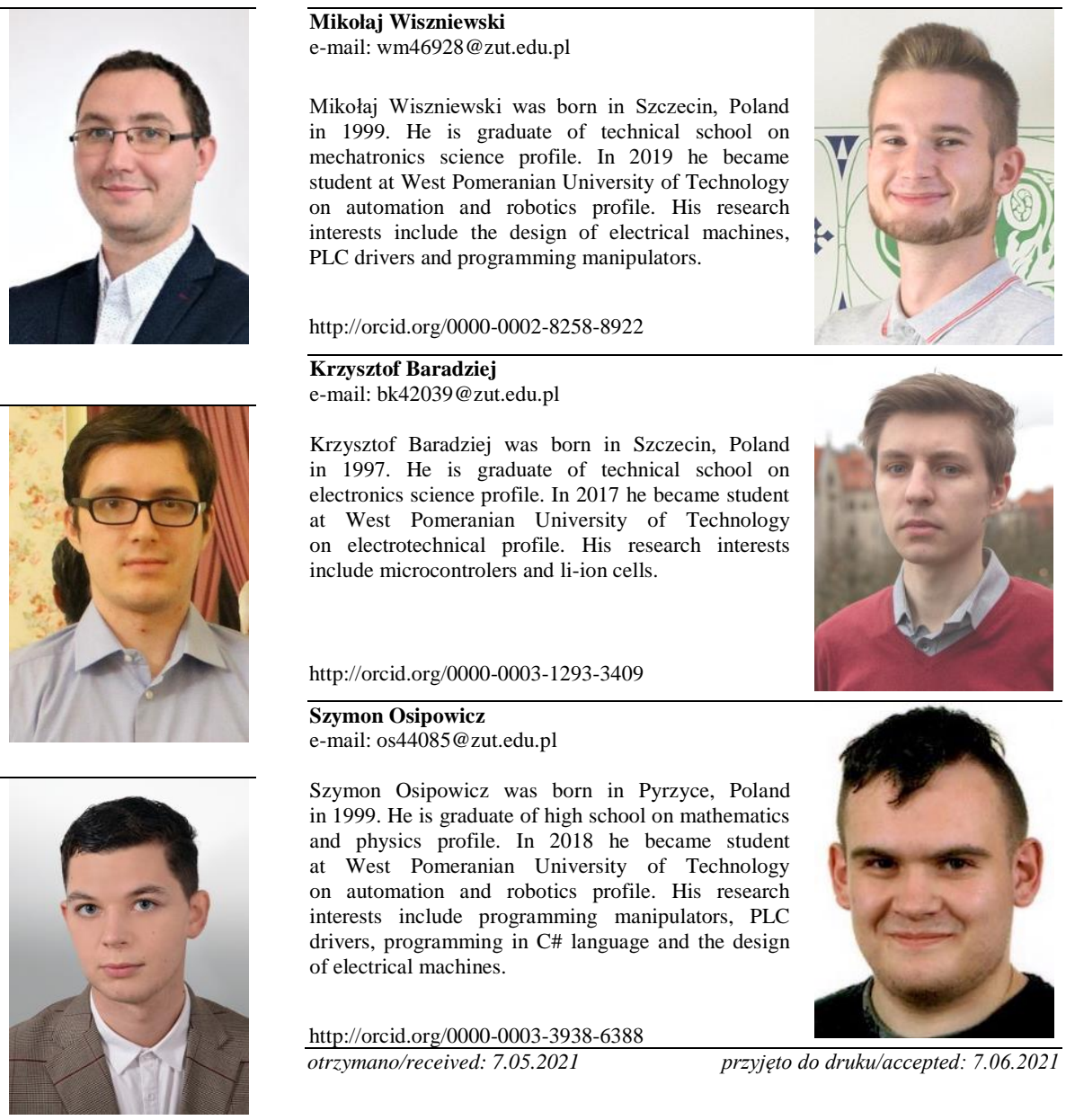

otrzymano/received: 7.05.202/ 